\title{
Legal Protection Against Children Being Victims Of Crimes Prosecution Stage In Kudus
}

\section{Dedy Nurjatmiko ${ }^{1}$}

Abstract. Protection of child victims in law enforcement process is essential to ensure the fairness of the essentials, in addition to criminal punishment to the perpetrators of the crime. This study aims to determine and analyze the consideration Requisitor prosecutors of the State Prosecutor of the case the defendant Child in Kudus of the rights of child victims. The method used in this research is juridical empirical method. Specifications research the authors use the descriptive analysis. Data collected in-depth interviews with the parties involved in research, direct observation and recording of documents. The survey results revealed the consideration of the Public Prosecutor in Requisitor yet fully protect the rights, rights of the victim, such as notifying the right to restitution.

Keywords: Protection of Child Victims; Consideration Requisitor Public Prosecutor; Restitution

\section{Introduction}

Pancasila is the basis for state and national ideology that took the logical consequence that the value of Pancasila used as a basic foundation for the implementation of the Unitary Republic of Indonesia. Contains five principles of Pancasila which essentially contains five basic fundamental values. ${ }^{2}$

The basic values of Pancasila is the value on God, Fair Value and Civilized Humanity, the value of the unity of Indonesia, the value of Democracy led by the wisdom role in consultative / representative, and the value of Social Justice For All People Indonesia. With a brief statement that the basic values of Pancasila is the value of the divine, human values, the value of unity, democratic values, and the values of justice. Precepts of Pancasila consists of the values and positive norms in accordance with the outlook of the nation of Indonesia. ${ }^{3}$

With still many cases of violence against children in Indonesia, such as physical violence, psychological, child exploitation, neglect to sexual violence is a reflection that the practice of Pancasila was still minimal value carried in daily life - today, especially the value contained in the second principle.

Kids as part of a young generation which acts as a transmitter ideals of the Indonesian struggle in the future have the right to grow and develop freely and without violence.

\footnotetext{
${ }^{1}$ Student of Masters (S2) of Law Faculty of Law Unissula Semarang and Functional Attorney in State Attorney Kudus Email dedinurjatmiko@gmail.com

2 Prima Roza Abdul Gani Yusuf dan Dicky R. Munaf 2016 Memahami Dan Memaknai Pancasila Sebagai Ideologi Dan Dasar Negara Gramedia Jakarta p. 5.

${ }^{3}$ Ibid.
} 
And to achieve this, children need a special protection, including legal protection different from adults so that children get the chance that an area of the extent to be able to grow and develop optimally.

Child protection efforts should be as optimal as possible, so that later the child can participate in nation building. One concrete manifestation of the state in providing legal protection for children is with the enactment. Law of the Republic of Indonesia Number 35 of 2014 on Amendment. Law of the Republic of Indonesia Number 23 of 2002 on Child Protection. The legislation contains legal norms that guarantee and protect the child rights for survival, as well as legal protection of children who become victims of crime. ${ }^{4}$

Child protection is an important work that should be done by all elements of our country. Child protection form was practiced from all aspects, ranging from coaching on family, social control over the association of children, and proper handling through good regulation made by a country.

Enforcement of criminal law as a last gate in order to bring the legal protection of children who become victims of crime are often disregarded. That is because law enforcement officials too much weight to the evidence for the actions of the perpetrators and criminal punishment against the perpetrators of such actions.

Prosecution as part of criminal law enforcement process should also realize justice in addition to legal certainty and expediency. To realize justice in the prosecution of criminal cases with child victims, then the prosecution process should consider the rights of children who are victims of crime.

Based on the pre-research of data obtained in the State Attorney Kudus, in 2017 there were criminal cases on behalf of AW Kids defendant charged with a felony obscenity or sexual intercourse against a child. During the process of prosecution by the prosecutors of the State Prosecutor of the Kudus turns out children who are victims of crime are not fully get legal protection. So that the parents of children victims of crime was not obtained justice.

Based on the above mentioned problems, the authors wanted to examine these issues in a scientific paper in the form of a journal under the title "Legal Protection Against Children Being Victims Of Crimes Prosecution Stage In Kudus".

Based on the background of the problems outlined above, the subject-matter of wanting to be appointed are: What is the rationale prosecutors of the State Prosecutor of the Kudus in the preparation of the warrant (requisitoir) in criminal cases on behalf of the defendant Son AW? How the implementation of the legal protection of the rights ? the rights of children who are victims of crime the prosecution to impose its ruling on the case on behalf of the defendant Son AW?

\footnotetext{
${ }^{4}$ Rika Saraswati 2015 Hukum Perlindungan Anak Di Indonesia Citra Aditya Jakarta p.31.
} 


\section{Result And Discussion}

\subsection{Basics of Public Prosecutions On State Attorney Kudus Demands In Preparing Letters (requisitoir) As well as the Advisory Council of the Kudus District Court Judge In Case BreakingIn the Name of the Son Accused AW}

Prosecution is the duty and authority of the Attorney institution Republic of Indonesia as stipulated in Article 30 paragraph (1) letter a Law of the Republic of Indonesia Number 16 of 2004 on the Prosecutor of the Republic of Indonesia.

In the exercise of power in the field of prosecution, Attorney of the Republic Indonesia mandated institutions such authority to the said authorities Prosecutor. Prosecutors are officials who are authorized by laws to act as public prosecutor and to implement a court decision obtained permanent legal force. ${ }^{5}$ In this case a prosecutor must obtain prior authority to perform the task of prosecution. Granting authority in the form of a written order (warrant) to carry out the prosecution. A prosecutor who has been given authority to conduct the prosecution called a public prosecutor.

Based on the above understanding can be concluded that the Prosecutor regarding Prosecutor's office at the Institute, while the public prosecutor regarding the function of the Institute of Public Prosecution. ${ }^{6}$

Prosecution itself is an act of the public prosecutor to delegate the criminal case to the district court authorities, who ordinances stipulated in the Act on request so examined and decided upon by the judge in court. ${ }^{7}$ In delegate a case to court, the public prosecutor must include the indictment. Because the indictment made by the Public Prosecutor is the basis for the judge, the defendant and / or the Legal Counsel and the Public Prosecutor in the trial of the case in court.

On the basis of the indictment made, the public prosecutor shall deliver a minimum of two (2) during the process of examination of evidence in court to prove his allegations on the defendant as described in the indictment. Evidence presented by prosecution can be: ${ }^{8}$

- Witness testimony;

- Expert testimony;

- Instructions;

- Letter;

- Description defendant.

After the inspection process has been declared finished, the Prosecution will file criminal charges in writing as provided for in Article 182 paragraph (1) letter a Criminal Procedure Code. Then defendant and / or the Legal Counsel will file a defense that can

\footnotetext{
${ }^{5}$ M. Yahya Harahap 2009 Pembahasan dan Penerapan KUHAP (Penyidikan dan Penuntutan) Edisi Kedua Sinar Grafika Jakarta p. 71.

${ }^{6}$ Muhammad Taufik Makarao dan Suhasril 2014 Hukum Acara Pidana Dalam Teori Dan Praktek Ghalia Indonesia Jakarta p. 20.

${ }^{7}$ M. Yahya Harahap Loc Cit p. 89.

${ }^{8}$ Ibid.
} 
be answered by prosecution provided that the defendant or the Legal Counsel is always a turn of the last (Article 182 paragraph (1) letter b of the Criminal Procedure Code). After the judge will do the final deliberations to take a decision (Article 182 paragraph (2) Criminal Procedure Code).

From the above it can be concluded that the Requisitor (requisitoir) is a letter that was made by the Public Prosecutor containing evidence indictment based tool the evidence revealed in the proceedings and conclusions of the Public Prosecutor Accused error accompanied by criminal charges. The demand letter also as a basis for the defendant and / or the Legal Counsel for the defense or refutation as well as the basis for the conduct deliberations judge to impose sentence.

In preparing the warrant, the Public Prosecutor be guided by the Attorney General Decision No. 518 / A / JA / 11/2001 dated 01 November 2001 on the amendment of Attorney General Decision No. 132 / JA / 11/1994 of the Administrative Case Crime. On the guidelines contained in the summons form code P-42 form. ${ }^{9}$

In the process of handling the case on behalf of AW Kids defendant in the State Attorney Kudus, Attorney Hapsoro Eko Pujiyanti, $\mathrm{SH}, \mathrm{MH}$ as the public prosecutor on the case said, consideration consideration in the preparation of its claim letter (requisitor) is divided into two (2) sections, namely the judgment juridical and nonjuridical considerations. In juridical considerations, Attorney Hapsoro Eko Pujiyanti, SH, $\mathrm{MH}$ lays out the formal juridical rules as the basis of the prosecution to conduct criminal acts committed by the defendant AW, whereas the non-juridical considerations, he would consider factors aggravating factor and ease revealed in the hearing.

At the formal juridical considerations, Attorney Hapsoro Eko Pujiyanti, $\mathrm{SH}, \mathrm{MH}$ emphasis to the rule (article) is being violated by AW accompanied Tedakwa criminal threat as well as other rules in the preparation of the ruling of the demands on his requisitoir. As the indictment the prosecutor, the defendant AW charged with alternatives, namely First: in violation of Article 81 paragraph (2) of the Constitution Child Protection Act, or two: in violation of Article 82 paragraph (1) of the Constitution Child Protection Act. Therefore, the public prosecutor demanded punishment should not be lower or higher than the threat of indictment article. In addition, the Attorney Hapsoro Eko Pujiyanti, SH, MH also consider factors other jurisdiction. The other juridical factors such as the defendant Son AW is aged less than 14 (fourteen) years, so that the defendant Son AW categorized as a child and should be processed through the juvenile justice system as stipulated in Act of the Republic of Indonesia Number 11 of 2012 on Child Criminal Justice System (SPPA Act).

Attorney Hapsoro Eko Pujiyanti, SH, MH re-tells the provisions of Article 69 paragraph (2) of the Act SPPA states, Children no older than 14 (fourteen) years may be subject

\footnotetext{
${ }^{9}$ Attorney General of the Republic of Indonesia Attorney General Decision No. 518 / A / JA / 11/2001 dated 01 November 2001 on the amendment of Attorney General Decision No. 132 / JA / 11/1994 of the Administrative Case Crime
} 
only, then the Article 82 paragraph (1) of the Act SPPA said, actions that can be imposed on the Child include:

- Returns to the parent / guardian;

- Submission to someone;

- Treatment in a mental hospital;

- LPKS treatments;

- The obligation to follow the formal education and / or training that was conducted by the government or private entities;

- Revocation of a driver's license; and / or

- Repairs resulting from a criminal act.

then in Article 82 paragraph (2) of the Act SPPA states, act referred to in paragraph (1) letter $d, e$, and $f$ subject to a maximum of 1 (one) year.

Attorney Hapsoro Eko Pujiyanti, SH, MH again explained that he also considers nonjuridical factors (subjective considerations) as well as juridical considerations in the preparation of the letter demands. On the subjectively consider, Attorney Hapsoro Eko Pujiyanti, $\mathrm{SH}, \mathrm{MH}$ describe non-juridical factors into consideration things burdensome thing and relieve the defendant. The thing the burden and relieve the defendant as set forth in claim letter is as follows:

- things aggravating factors:

- Children actions have damaged the future of the victim, which is still the age of 8 (eight) years;

- Kids act causing victims often feel pain in the vagina;

- Children act disturbing residents, especially residents of the village Tanjungrejo.

- things mitigating factors:

- Child as the future generation who still have a chance to improve their attitudes and behavior;

- Kids have not been convicted;

- The child acts carried out due to lack of supervision of the family.

From the foregoing considerations, the Attorney Hapsoro Eko Pujiyanti, SH. MH. believes the most appropriate action against the defendant is in the care of Social Welfare Institution Operator (LPKS), namely in Marsudi Putra Social Institution Antasena Magelang for 1 (one) year as well as the imposition of criminal fines of Rp. 500.000.000, - (five hundred million rupiah) Subsidiary Training for six (6) months at the Vocational Training Center (BLK) saints.

\subsection{Implementation of Legal Protection of the Rights of Children Being a Victim of Crime Prosecution Process Up Case Against Imposition Decision on Behalf Defendant Son AW}

Enforcement of criminal law against perpetrators of crimes against children should not be alone eyes are on the subject of the criminal perpetrators, but also consider the rights of the rights of children as victims of crime. Law enforcement in this case must 
consider the interests of children, because children who are victims of crime will have problems in mental and psychological development. Therefore, by providing the right the rights of children who are victims of crime in the process of law enforcement, the legal protection of children can be met.

Prosecution as part of criminal law enforcement process should also realize justice in addition to legal certainty and expediency. To realize justice in the prosecution of criminal cases with child victims, then the prosecution process should consider the rights the rights of children who are victims of crime.

Pursuant to Article 64 paragraph (3) of the Constitution of the Republic of Indonesia Number 35 of 2014 on Amendment of the Republic of Indonesia Number 23 of 2002 on Child Protection. Child Protection Measures implemented through:

- Medical and psychological rehabilitation efforts, either through the institution and outside the institution;

- Safeguard the preaching of identity through the mass media and to avoid labeling;

- Giving assurance of safety of witnesses and victims and expert witnesses, whether physical, mental, and social;

- Provision of accessibility to information about the development of the case;

In addition to the right above rights, the provision of legal protection for victims of crime also get the right to apply to the Court in the form of the right to restitution is the responsibility of the perpetrators under Article 71D Act of the Republic of Indonesia Number 35 of 2014 on Amendment of the Republic of Indonesia Number 23 of 2002 on Child Protection

That the prosecution of the case the defendant Son AW in the State Attorney Kudus, Attorney Hapsoro Eko Pujiyanti, $\mathrm{SH}, \mathrm{MH}$ as the public prosecutor handling the case was explained during the prosecution of criminal cases on behalf of the defendant Son AW, he has been providing legal protection for children who are victims of crime, namely Witness SM entitlement the child rights include:

- Right to be accompanied by parents when done at this stage of the examination in court;

As SM Witness parents request that their child is experiencing psychological stress inflicted AW Kids defendant, so it takes the role of parents so that victims can be more convenient to explain chronological events of the crime that happened.

- The right to receive treatment and medical examination of the injuries suffered by the victim offender inflicted.

Treatment and medical examination was carried out by a doctor to injuries obtained casualties inflicted actors, especially sores on the genitals Witness BC From the results of the examination, the doctor who performs the treatment and medical examination will contain results of the investigation in the form of letter post mortem ,

- The right to a separate examination of sexual offenders. 
That during the examination of the witness SM at trial, the defendant is temporarily excluded from the trials and the right to ask the defendant authorized to the General Counsel. It aims to avoid intimidation defendant to the victim during the hearing.

- The right to guarantee anonymity.

That the trial of criminal cases on behalf of the AW Kids defendant held behind closed doors. It is intended that the identity of the witness SM is not published.

- The right to obtain information on the progress of criminal cases on behalf of the defendant Son AW

Eko Pujiyanti that prosecutors Hapsoro, $\mathrm{SH}, \mathrm{MH}$ as the public prosecutor had told the parents SM Party concerning the determination of the trial court.

That based on the description above it turns out there is a right which have not been met during the prosecution process which should be the right of Witness $\mathrm{BC}$, namely the right to be notified of Public Prosecutions on the submission of restitution is the responsibility of the defendant Son AW

\section{Closing}

\subsection{Conclusion}

- Attorney Hapsoro Eko Pujiyanti, SH, MH as the Public Prosecutor of the State Attorney Kudus who handles criminal cases on behalf of AW Kids defendant has made consideration judicial and non-judicial in drafting the letter demands.

- In the prosecution of criminal cases on behalf of the defendant Child Survivors rights exist AW SM child who has not been given, namely the right to be notified of the filing of the Public Prosecutor of the right to restitution is the responsibility of the defendant Son AW

\subsection{Suggestion}

In order for the law enforcement authorities, especially the Public Prosecutor in the prosecution of criminal cases on behalf of AW Kids defendant to be around the Witness rights of child victims of $B C$ so that the values of justice can be realized.

\section{Bibliography}

[1] M. Yahya Harahap 2009 Pembahasan dan Penerapan KUHAP (Penyidikan dan Penuntutan) Edisi Kedua Sinar Grafika Jakarta.

[2] Muhammad Taufik Makarao dan Suhasril 2014 Hukum Acara Pidana Dalam Teori Dan Praktek Ghalia Indonesia Jakarta.

[3] Prima Roza Abdul Gani Yusuf dan Dicky R. Munaf 2016 Memahami Dan Memaknai Pancasila Sebagai Ideologi Dan Dasar Negara Gramedia Jakarta.

[4] Rika Saraswati 2015 Hukum Perlindungan Anak Di Indonesia Citra Aditya Jakarta.

[5] Constitution of the Republic of Indonesia of 1945 (amended version of I s / d IV); 
[6] Law of the Republic of Indonesia Number 8 of 1981 on the Law Criminal Law (Criminal Code);

[7] Law of the Republic of Indonesia Number 35 of 2014 on Amendment of the Republic of Indonesia Law Number 23 of 2002 on Child Protection;

[8] Law of the Republic of Indonesia Number 11 of 2012 on Juvenile Justice System;

[9] Decision prosecutorSupreme Decree No. 518 / A / JA / 11/2001 dated 01 November 2001 on the amendment of Attorney General Decision No. 132 / JA / $11 / 1994$ of the Administrative Case Crime 